\title{
THE CHANGING LANGUAGE POLICIES AND REVERSING LANGUAGE ROLES IN MALAWI: FROM COLONIAL TIMES (1891- 1964) TO THE PRESENT
}

Themba Moyo

University of Zululand

This article attempts to chart the language policies that Malawi has followed from colonial times (1891-1964) up to the present. The focus falls on the roles accorded to indigenous languages and English in national life and communities, respectively. In Malwi, the value of mother tongues or languages widely used by particular communities is recognised and these languages are used as instructional languages in early education. This is done to enable learners to understand basic concepts and to facilitate cognitive development. It is also to ensure that there is a smooth transition to English, which becomes the medium of instruction in standard five. The use of mother tongues and community languages of wider communication also plays an important role in the development of pride in, respect for and affiliation with mother tongues and cultural identity. It appears that there is a crucial need to for language policy in Malawi to be reviewed. To date it has been politically motivated, fragmentary and often not effectively implemented. This is particularly true since Malawi gained its independence in 1964. President Bakili Muluzi has seen the value of developing viable indigenous languages as well as some of those spoken by a small minority, However, since his election to power, language issues have received little attention: the policies he promised have not been implemented.

In hierdie artikel word gepoog om die verskillende taalbeleide wat Malawi sedert sy koloniale tydperke (1891-1964) tot op hede gevolg het in perspektief te plaas. Die fokus val op die rolle wat toegeken is aan die inheemse tale en Engels op nasionale vlak en in gemeenskappe. In Malawi word die waarde besef van moedertale of tale wat algemeen gebruik word deur spesifieke gemeenskappe. Hierdie tale word tydens vroeë onderwys as onderrigtale gebruik. Dit word gedoen om die leerders in staat te stel om basiese begrippe te verstaan en om kognitiewe ontwikkeling te fasiliteer. ' $n$ Ander rede is om te verseker dat die oorskakeling na Engels as onderrigmedium in standerd vyf glad sal verloop. Die gebruik van moedertale sowel as gemeenskapstale van groter gemeenskappe dra ook daartoe by om ' $n$ trots in, respek vir en affiliasie met die moedertaal en kulturele identiteit te ontwikkel Die kom voor asof daar ' $n$ groot behoefte in Malawi is om die taalbeleid te hersien. Tot nou toe, veral sedert Malawi se onafhanklikheidswording in 1964, was die taalbeleid polities gemotiveerd, fragmentaries en is dikwels nie effektief geïmplementeer nie. Ten spyte daarvan dat president Balili Muluzi sedert sy verkiesing in 1994 die waarde begin besef het van die ontwikkeling van lewensvatbare inheemse tale en sommige tale wat deur ' $n$ klein minderheid gepraat word, het taalkwessies baie min aandag gekry: die beleide wat hy belowe het, is nog nie geïmplementeer nie. 


\section{INTRODUCTION}

This article outlines the language policies that Malawi followed from the colonial period, to the present. When the country gained its independence, colonial language policies were inherited, which was largely acceptable to the citizenry.

Dr Hastings Kamuzu Banda was Malawi's first president after the country's independence in 1964. As a result of his language policy, there was a English-Chichewa diglossia. In this sense he can be said to have failed to recognise the fundamental role and function of indigenous languages other than Chichewa. Consequently, these languages and cultures were marginalised to languages of village use or tribal identity only. In 1996 the present government promoted five indigenous languages (in addition to Chichewa) to official status. However, this was largely gestural political. This means that the country does not yet have a coherent or clearly defined language-in-education policy nor a language policy for mass communication at national level. The 'elaborative creation of power' in which issues of language and cultural development for the entire populace are equitable and critical, or what Cummins (1994: 54) terms language empowerment, has not been effected.

\section{THE LANGUAGE POLICY AND LANGUAGE SITUATION IN COLONIAL TIMES}

Malawi, then Nyasaland was a British Protectorate from 1891-1964. In education, the policy was to use the vernaculars as media of instruction in early education. There were three categories of schools: the vernacular, Lower Middle and Upper Middle. English was used in the Lower Middle Schools and in time it became the medium of instruction. By 1902 there were eight missions working in the country (Kayambazinthu, 1988:20). As part of their programme of evangelising or prosetylising the local people, texts were produced in local languages. While there were and still are many indigenous languages, ??the differences were reduced in writing in line as a matter of practicality.. The northern region, for example, has five districts in which the following languages are spoken: Kingonde, Chilambya, Chitonga, Chitumbuka and Chingoni. While Kingonde and Chitonga were at times used as instructional languages Chitumbuka, the language of the majority of native speakers in the region eventually emerged as a common language for all learners in the north. All learners attained proficiency in this language and the language, therefore, became established as the regional instructional language.

In the central region with nine districts Chinyanja or Chichewa (the two names refer to the same language) emerged as the instructional language with many native speakers than those who of other ethnic groups. There are, however, speakers of other languages such as Chitumbuka in Kasungu, Chiyao along the lakeshore in Salima up to Chipoka and Ngoni in Dedza and Ncheu districts. Besides, that there are also the Senga and Nyanja ethno-linguistic groups in the centre. In the southern region Chinyanja/Chichewa or Chimang'anja, as it has at times been referred to, emerged as the instructional language. The southern region, however, also has native speakers of Chiyao, a viable language at regional and national level as well. There are also native speakers of Chilomwe in Mulanje and Thyolo districts and speakers of Chisena in the Lower Shire. Chisena has been also referred to as a dialect of Chimang'anja or Chinyanja. It is important to note that an important aspect of the diverse ethno-linguistic composition of the country is the lack of a single ethnic group (Chirwa, 1994:99). There is no one ethnic group that constitutes the 'majority tribe' as Dr Banda claimed. This is because such as claim has no accurate demographic evidence or ethnographic validity (Africa Watch, 1990:57). 
From this diverse ethno-linguistic composition the missionaries chose to reduce into writing only three languages in the end: Chitumbuka in the north, Chichewa/Chinyanja in the centre and Chinyanja/Chimang'anja in the south. Chiyao was abandoned because it was viewed as a language of Islam. The missionaries viewed it as 'a dangerous menace to their own efforts of Christianising and civilising the Africans along western lines' (Kishindo, 1994:133). As media of instruction then two indigenous emerged in the country, Chitumbuka for the north and Chinyanja/Chichewa or Chimang'anja for both the central and southern regions. The two languages also emerged as languages of mass communication at national level, with English as the official language.

Davis (1992) has argued that there are a number of children all over the world who acquire education in a second language; and the acquisition of education in a second language does not necessarily retard their academic achievement. This supports the argument that while there are different ethno-linguistic groups through out Malawi, only two languages emerged in the colonial times as languages of instruction. As long as learners attained proficiency and competence in either Chitumbuka and Chinyanja/Chichewa/Chimang'anja, they were able to acquire different concepts and develop their cognitive skills these in indigenous languages, which later facilitated their learning of the instructional language of higher learning, English. We have to note again that the Davis' (1992) argument does not deny the importance and role of mother tongue instruction in being the most suitable instructional language besides developing the child's pride and appreciation of his/her own native language and culture as the child grows up.

Awoniyi (1982:1) has maintained that the mother tongue is associated with the child's growth and development and that it is through language that personality and experience are expressed.

\section{Dr Hastings Banda's language policy at independence, 1964.}

Dr Banda was Malawi's first president from 1964-1994. For thirty years he established an autocratic repressive government. Like other former British colonies, which had attained independence, Dr Banda adopted English as the official language of government and economy. He initially (for four years only) also adopted Chitumbuka, which had long emerged as the regional lingua franca in the north and Chinyanja/ Chimang'anja as the lingua franca in central and southern regions as instructional languages, in early educational and also for mass communication on the state radio and in print media.

\section{Change in Dr Banda's language policy in 1968.}

Four years after independence, at the annual convention of the Malawi Congress Party (MCP), whose theme for thirty years was always 'building the nation'; Dr Banda decreed and strongly recommended the following as he claimed in the interest of national unity:

- Malawi adopt Chinyanja as a national language;

- that the name of the language, Chinyanja, be changed to Chichewa (Chichewa was Banda's own minority dialect of Chinyanja.) 
- that English be elevated to its usual status of an official language and Chichewa to the status of a national language. The rest of the other languages would be used as languages of villages use and identity in their communities.

This marked the demise of Chitumbuka as a regional lingua franca and as an instructional language in the northern region and also as a language of mass communication on the radio and in print media as stated earlier. Kishindo (1994:137) has noted that these recommendations came to be the basis of Malawi's language policy.

Dr Banda's new language policy attracted various comments from academics and others concerned in language matters. Dr Banda himself, from the 1966 census count, claimed that the Chewa constituted the majority tribe in Malawi and hence the choice and elevation of the Chewa dialect into a national language of symbolic importance. It has also been argued that while the issue of national identity and nation building could be invoked to justify the adoption of one language as the national languages the strategy adopted in Malawi amounted to an imposition of a language on a people. The lack of 'consultation led to resentment among the other people towards both the policy as a whole and the change of the name from Chinyanja to Chichewa '(Mchombo, 1998)'. Matiki (1997:527) an academic, has observed that Chichewa was chosen as the national language because it was President Banda's mother tongue. Chirwa 1994/95 an academic and intellectual has observed that the elevation of Chichewa to a national language became a dominant strand of the Malawi cultural fabric. John Lloyd Lwanda, medical doctor and interested in the affairs of his country, where he no longer lives, has referred to this pronouncement as a process of Chewaisation. He has argued that in the quest for Chewa domination those tribes that had developed strong cultural traditions or saw themselves as different, suffered from the policy because their identities had to be subordinated to varying extents of Chewaisation. In particular these were those ethnolinguistic groups from the south such as Nyanja or Mang'anja, the Yao and the Lomwe. This has been further noted that their cultural and historical traditions were subtly, but systematically subordinated to those of the Chewa (Chirwa, 1994/95:61). This was besides alienating the north with an established Chitumbuka dynasty, a strong culture and political institutions as well. (Mchombo, 1998). What Lwanda means by the process of Chewaisation is that Dr Banda was bent on promoting the idea of Chichewa as the most superior language and culture, with the sole aim of making both the language and its culture synonymous with Malawi (Africa Watch, 1991:35).

The other implication of this new language policy was that Chichewa became the instructional language in early education from standard 1 to 4 through out the country. It has since then been the only indigenous language studied in secondary schools and studied at university level to date. This was regardless of whether the learners and teachers had attained proficiency in the language or not. The policy particularly affected learners and teachers in the north, most of who, could hardly speak the language or understand it. From this pronouncement many came to view Malawi blindly as a monolithic state. They were oblivious of the fact that the country is multi-lingual with well over 8-14 ethnolinguistic groups and cultures, depending on the analysis of the linguist.

\section{The English-Chichewa hegemony and predominance.}

Why English as Malawi's official language? The choice of English in Malawi, post-colonial Africa and elsewhere in the world goes beyond the notion of better opportunities for higher education and subsequent better employment prospects. For purposes of communication 
across Malawian borders, English is still, largely, the preferred language in diplomatic discourse, international trade, particularly outside Zambia and Mozambique and also the language of cultural diffusion, to some considerable extent. There is also the argument that a considerable number of western market-driven economies, particularly in developing countries, prefer English for hegemony reasons. (Tollefson, 1991).

Donor countries prefer to use English as a means of controlling access to power, and the promotion of their aid packages is seldom via indigenous languages (Heugh, 1993). This is, however, not to say that English is necessarily biased towards capitalism. It is employed here purely as a language of international communication. However, if equal opportunities are to be a reality, for the majority of the population in Malawi, which is no exception to the notion of hegemony as the rest of anglophone Africa is, then surely the status of viable indigenous language has to attain overt recognition beyond the Chichewa language alone.

Indigenous languages have to become a reality to become functionally viable. One way of assuming this would be their official elevation in transactional communication roles, along with English in the socio-economic as well as in the political life of the majority. Unless the status of viable languages and even minority languages in their respective communities is elevated, these functional roles, for languages such as Chitumbuka and Chiyao are likely to be assimilated and relegated to a status of second languages of disempowerment. This would result in little influence in the general empowerment of a people's lives, socially, economically, culturally and politically.

This is a particularly important factor to consider in Malawi where $80 \%$ of the 9.7 million population lives in rural areas (Osman, 1994). Only a small elite has emerged, most of, which is more literate in English than in Chichewa, or any other indigenous language. It has also been observed that by "virtue of its confinement English is not a language of mass communication but of power and prestige, hence its limited spread but plays a crucial role in the running of the country.... It is also the main language of the court beyond the lower courts. In the magistrates' courts and high courts, interpretation services for people who do not understand English is available. All laws, statutes, decrees, directives, rules and regulations, contracts and documents pertaining to them are in English, making them inaccessible to the average Malawian and empowering the elite' (Kayambazinthu, 1988:29).

Another hegemony of English and Chichewa is in the literary industry since the 1968 president decree. There has not appeared a short story, a poem, a play or a novel published either on the state owned Malawi Broadcasting Corporation's programmes, the Writers' Corner or Theatre of the Air or in publishing houses in print, in any of the other indigenous languages, except in English and Chichewa. This translates into saying that there are adults who are well over thirty six years old, who have not seen nor read any work of art, or indeed any other, in Chitumbuka, Chiyao, Chilomwe, Kingonde etc.(Moyo, 2000. Chichewa thus came to be employed at a tool for 'transforming' all other cultures into a single national identity through a process of political mobilisation of Dr. Banda's language policy and repressive one- party government.

Kamwendo (1997:36) observed that Chichewa was meant to marginalise other indigenous languages, where human and linguistic rights such as freedom of expression were denied. This could only mean that other indigenous languages face the death or extinction, which still looms particularly in print. This is where not a single indigenous language appears either in the newspapers or literary texts other than in English and Chichewa. It has been further noted 
that the Chichewa Board, replaced by the Centre for language Studies in 1996 also entrenched the role of Chichewa. It promoted the Chewa identity even in panel discussions, which were held on weekly radio programmes 'on how to speak and write Chichewa correctly. Other languages were denied this development' (Kamwendo, 1997:41).

\section{The 1996 United Democratic Party's (UDF) reviewed language policy.}

Dr Banda's dictatarial rule came to an end in 1994 with the rise of multipartism. Bakili Muluzi, a Yao from the south won the elections with an overwhelming majority. However, his performance at the poll outside the southern region was not very impressive, particularly in the centre and in the north. The press noted that voting was largely along ethnic lines in that the voters in the north, which is comparatively sparsely populated region voted for their Tumbuka candidate, Chakufwa Tom Chihana. Those in the centre voted for their Chewa candidate, Dr Banda. The south, which is the country's most industrialised and densely populated also, voted for their candidate from the South, Bakili Muluzi.

The UDF came in with its new language policy. Chitumbuka was reinstated as an official language. Four other indigenous languages in all were also elevated to the official status as official languages. These were Chitonga, Chiyao, Chilomwe and Chisena. In all there are now six official indigenous language including Chichewa. Along with English there are altogether seven official languages. However, these are of unequal official status. Before we go into this, let as examine how they were elevated to this new status. It could be argued that the elevation of the five indigenous languages to official status was based on the following: Chiyao was promoted to the official status because it is the current president's mother tongue. Chitumbuka was elevated because people from northern Malawi did not particularly favour the new president and this step was meant to appease them (Matiki, 1998:22).

The elevation of Chisena was made because Peter Fachi was then minister of Justice and Attorney General. He represented the Sena ethno-linguistic group in the hierarchy of political stalwarts within the UDF's structures. Chitonga, a language spoken in one district of the country only, was elevated because it was also represented by Aleke Banda (no relation to the former Head of State), but another influential politician who was then deputy head of the ruling UDF party. Since the 1994 voting was on ethnic lines he also wanted to entrench his position by elevating the language of his home where UDF did not have much support from the local community in the 1994 elections. This would then possibly secure his seat in the next poll. For similar reasons. Chilomwe, a language that supposedly represents a considerable number of people in Thyolo and Mulanje districts, which are also the most denseley populated districts in the country, because of the large tea estates industry came to be promoted to an official status. Interestingly, no one has heard Lomwes normally speak the language until it became elevated to an official language. This was the first time that many Malawians even those non-Lomwe workers working in the tea estates heard of it on the news broadcast on the radio. It was represented by Brown Mpinganjira, a Lomwe and reportedly, the most powerful minister then who wielded a lot of political power within the ruling UDF government (Moyo, 2000:156).

It is quite clear that the elevation of these indigenous languages to the official status, much as some of them may well be viable languages regionally or nationally such as Chiyao, was not based on sociolinguistic surveys to determine the status they attained. We could only argue that they were promoted to the status they hold because they represent or presented the political heavyweights within the UDF. This was in order to gain support from the masses at 
that time and also secure the politicians' retaining their reelection at the next poll, which they all retained in 1999. It would appear that this was only a carry-over from Dr Banda's tactics of entrenching his dialect which subsequently became a national language in his own Chewa base in the name of achieving national unity.

\section{The UDF's language-in-education policy.}

Further to the pronouncement or elevation of five more indigenous languages to the official status the Ministry of education issued a directive, in the form of a letter from the Secretary for Education Ref.IN/2/14, dated $28^{\text {th }}$ March 1996. This directive informed the nation that, with immediate effect, all standards 1, 2, 3 and 4 classes in all schools would be taught in their mother tongues or vernacular as the media of instruction. English and Chichewa would, however, continue to be offered as subjects in the primary curricula. In the past, it has to be remembered that all initial education was in Chichewa regardless of whether the learners and teachers had knowledge of the language or not. English would, however, be the medium of instruction from standard five (Kayambazinthu, 1988:33).

Different from Dr Banda's policy of Chichewa only in education as the medium of instruction, this assigned five other vernacular languages other than Chichewa in the national education system. It has to be seriously noted, however, that 'this directive preceded the training of teachers, preparation of materials and resources and general research into the current language situation and attitudes in Malawi. Because of the impromptu nature of the directive, it is not surprising that it is failing to implement the policy. The ministry continues to Post primary school teachers where they are needed regardless of whether they know the language of the community or not, thus contradicting the declaration and its intentions. The failure of the plan is related to the lack of adequate background planning before the policy was decreed. The policy also contradicts other relevant provisions against the background of availability of physical and material infrastructure for the successful implementation of such a policy in Malawi'

(Kayambazinthu, 1988:33).

The pronouncement or elevation of five other indigenous languages to the official status in mass communication, along with the new language-in-education policy marked the UDF's government policy of Zinthu zasintha, meaning 'things have changed.' In effect little else had changed other than those rhetorical pronouncements.

If we consider the use of the elevated five indigenous languages on the radio, their role is only token. They are heard in ten-minute news slots each in their respective languages and no more. They are not featured in any educational or entertainment programmes other than in news broadcasts alone. On the other hand, Chichewa and English continue to dominate the airwaves.

With regard to the language-in-education policy, teaching and learning materials have not been produced for there to be effective mother tongue instruction. There was the philosophy of Zinthu zasintha (things have changed) which has not been implemented either. Very little progress such as research on peoples' attitudes towards mother tongue has been carried out in collaboration with the University of Malawi. It could only have been for political expediency that the two policy statements were pronounced. 


\section{General assessment and observations.}

From the foregoing discussion we note that the two governments that have been in power since Malawi attained her independence from 1964 to date have not seriously considered the development of both viable and minority languages in the country. Dr Banda's government, which reigned from 1964-1994 failed to give official recognition, identify and develop each of the country's languages to its community toward national development as a whole. We could argue that 'the mentality of any nation is measured by the mentality of its citizens... This is necessary for social, economic and moral progress of society. If democracy is to survive in Africa, then Africans must be able to read government policies and to understand in what manners, the policies affect them' (Walusimbi, 1997:555). This seems not to have taken root in Malawi among the politicians who are in the end language policy decisionmakers. Very little seems to have been invested in literacy-education and in the recognition of viable and minority languages as a whole.

The non-development of other languages in a multilingual country does not foster national unity. Unity could still be attained in diversity. If anything, the dominance of Chichewa has particularly raised acute inter-ethnic rivalries since Dr Banda's rule. Unfortunately his mindset seems to have been continued into present government as well. In Dr Banda's government it was not stated which machinery would be responsible for the effective implementation of policy statements other than himself in public meetings or rallies, and the function of the Censorship Board which was charged with the development of Chichewa alone. However, it failed to produce a Chichewa dictionary which was its a major mandate. This was in the 22 years of its life. In the present Muluzi government, the Centre for Language Studies has made a modest start. Its objectives are to focus in the development three viable languages it has identified, in the absence of statistical evidence, viz, Chichewa, Chiyao and Chitumbuka. Its progress, however, can only depend on the government's will and on much the government is willing to fund it in order to carry out research in the various languages.

The policies that Malawi has made thus far remain unclear and lack implementation, direction and largely commitment to policy issues. The problem of the fear of cost as in developing viable languages and minority languages is understood but, at least, some measure of effort should have been made, which does not seem to be there.

Language experts, educationists and government officials agree, for example, that there are not enough teachers to cope with the teaching load required by the needs of Malawian indigenous languages, apart for English language teachers. However, recommendations on these issues have gone unheeded. There seems to be a lack of consideration between what is to be done at various levels of the political and education system because of poor coordination and incoherent policy statements. While cost could be cited as the major reason, it seems obvious that the will is also lacking on the part of the politicians who control the running of the government (cf: Elugbe, 1997: 466).

We would suppose that educational and national programmes should attempt to reflect national goals and aspirations for government policies towards equitable development for all. Policy statements on paper alone are not enough without implementation.

As identified by the Centre for Language Studies (CLS) the focus on the development of Chichewa, Chiyao and Chitumbuka has to be accelerated. This is more for those to become 
professionals in journalism, public relations, broadcasting, nursing and medicine, receptionists and revenue collectors, etc. The functional importance of these languages should be emphasised up to the Malawi School Education Certificate (MSCE) level and possibly beyond, in all viable languages. One fails to see how those in the cited professions can effectively function without being sufficiently proficient and literate in these indigenous language.

\section{CONCLUSION}

This article has sought to focus on language policies and the roles played by languages in Malawi. This is from colonial times to the present. In this, the article has recognized the importance of mother tongues as mediums of instructions in early education for the conceptual and development of cognition in the learner. This is apart from the learner growing up with pride in his/her language and culture. However, it has also noted that in absence of such a mother tongue emerging as an instructional language, the language of the wider community where the learner is, which may not necessarily be the learner's mother's tongue could also be used as a medium of instruction in early education as long as proficiency has been attained in that language. An example of this has been cited of the use of Chitumbuka, which many learners use as the medium of instruction in northern Malawi. The mother tongue or community language, therefore, constitutes the bedrock of the country's educational and cultural manifestations. The two occupy an important place in moulding learners educationally, socially, culturally and politically as well. English is facilitated as the language of higher education and international communication if sufficient proficiency and competence has been grounded in the learner.

In the end what we note is that Malawi has without doubt, in my view, gone through considerable linguistic and cultural derailment. This is largely because of its incoherent and fragmentary language policies and functions of languages. This is particularly from the attainment of independence in 1964 to the present. Putting into place well-defined, systematic and coherent language policies, both for the education system and for equitable purposes in mass communication in the national life for all can only prevent this. We need to observe that this entails 'the preservation and celebration of the linguistic and cultural pluralism that characterises most African countries' (Mchombo, 1998: 44).

\section{REFERENCES}

AFRICAN WATCH. 1990. Where Silence Rules: The Oppression of Dissent in Malawi: New York, Washington DC. and London: Human Rights Watch.

1991. Academic Freedom and Human Rights, Abuses in Africa : An African Watch Report. New York: Human Rights Watch.

AWONIYI, T. 1982. The Teaching of African Languages. Nigeria: Nigeria Publishers' Service.

BODOMO, AB. Linguistics, Education and Politics: An Interplay on the Study of Ghanaian Languages. In Herbert, R.K. (ed). African Linguistics at the Crossroads: Papers from Kwaluseni. 555-562. Köln: Rüdiger Köppe. 
CHIRWA, WC. 1994. The Politics of Ethnicity and Regionalism in Contemporary Malawi: In African Rural and Urban Studies. Vol.1.No.2. 93-118.

1994/95. Regionalism, Ethnicity and the National Question in Malawi: In SAPSE Research. Dec/Jan. 59-62.

CUMMINS, J. 1994. Knowledge, Power and Identity in teaching English as a Second language: the whole child, the whole curriculum, the community. Cambridge: Cambridge University Press.

DAVIS, A. 1992. The Native Speaker in Applied Linguistics Edinburgh: University Press

ELUGBE, BO. Literacy and Language development in Nigeria. In Herbert, R.K. (ed). In African Linguistics at the Crossroads: Papers from Kwaluseni. 455-468. Kiln: Rüdiger Köppe.

HEUGH, K. 1993. The place of English in relation to other languages in South Africa. In Per Linguam. Vol. 9. 2-9.

KAMWENDO, GH. 1997. The Language Rights in the Dictatorship: The case of Malawi during Dr Banda's rule. In Language Matters: Studies in the Languages of Southern Africa. Issue No.28. 3-50.

KAYAMBAZINTHU, E. 1988. The Language Planning situation in Malawi. In Journal of Multilingual and Multicultural Development. Vol. 19. No. 5 and 6. 32-66.

KISHINDO, P. 1994. The Impact of a National Language on Minority Languages: The case of Malawi: In Journal of Contemporary African Studies. Vol.12. No.2.127-150.

LWANDA, JL. 1993. Kamuzu Banda of Malawi: A study in Promise, Power and Paralysis. London: Dudu Nsomba Publications.

MATIKI, AJ. 1997. The Politics of Language in Malawi: A preliminary investigation In Herbert, R. K. (ed). 520-539. African Linguistics at the Crossroads: Papers from Kwaluseni. Köln: Rüdiger Köppe. Studies Centre. 1998. An Exploration of Language issues in Malawi. Boston : African

MCHOMBO, SA. 1998. National Identity, Democracy and the Politics of Language in Malawi and Tanzania. In Journal of African Policy Studies.

No 4.1.33-46.

OSMAN, A. 1994. Apathy is the front runner as Malawi Election Looms In Sunday Times. March. 20.

MOYO, CT. 2000. Formulating Effective Policy: Issues in Language and Education in Malawi. Unpublished D.Phil. Thesis, University of Zululand.

TOLLEFSON, JW. 1991. Planning Language, Planning Inequality. London: Longman. 
T Moyo

WALUSIMBI, L. 1997. The future of minority languages in Uganda. In Herbert, R.K. (ed) African Linguistics at the Crossroads: Papers from Kwaluseni. 555-560. Köln: Rüdiger Köppe.

\section{Biographical Note}

Themba Moyo is acting head of the Department of General Linguistics. (email: ctmoyo@pan.uzulu.ac.za; tel: $035-902-6321)$ 